\title{
Secondary School Teacher's Perceptions of the Role of Social Studies in Fostering Citizenship Competencies
}

\author{
Keene Boikhutso ${ }^{1}$, Baamphatlha Dinama ${ }^{1} \&$ Moffat Fanah Kgotlaetsile ${ }^{2}$ \\ ${ }^{1}$ Faculty of Education, University of Botswana, Gaborone, Botswana \\ ${ }^{2}$ Serowe College of Education, Serowe, Botswana \\ Correspondence: Keene Boikhutso, Faculty of Education, University of Botswana, Gaborone, Botswana. Tel: \\ 267-355-2374. E-mail: Boikhutso@ mopipi.ub.bw
}

Received: May 9, 2013 Accepted: May 21, 2013 Available online: June 14, 2013

doi:10.11114/jets.v1i2.152 URL: http://dx.doi.org/10.11114/jets.v1i2.152

\begin{abstract}
This study investigated the perceptions of the role of Botswana's social studies teachers at secondary school level in fostering citizenship competencies and skills. Survey questionnaires were used to collect data comprising close and open-ended questions. The total population comprised forty-one respondents purposively sampled from nine junior and senior secondary schools in rural and urban locations. These included thirty four social studies teachers and seven head of departments. Data were analyzed quantitatively using descriptive statistics. The findings revealed that, contrary to expectations the Botswana's social studies curriculum does not promote the acquisition of citizenship skills. There is a disconnection between what social studies teachers think they do and what actually happens on the ground. In fact, the mere teaching of citizenship skills does not automatically translate into equipping learners with the relevant and appropriate competencies. Successful implementation of citizenship education requires political commitment and social studies teachers who are well trained and competent to handle educational reforms.
\end{abstract}

Keywords: citizenship, social studies, curriculum, competencies, skills, perceptions

\section{Introduction}

\subsection{The Problem}

There is a close link between social studies and citizenship education given that they both emphasize social participation, active student engagement and the use of discovery or inquiry learning. This paper is motivated by the need to establish the extent to which the teaching and learning of social studies fosters the acquisition of citizenship competencies. To do this, the paper specifically examines the perceptions of the Botswana's social studies teachers in the secondary schools regarding the extent to which social studies fosters citizenship competencies and skills. However, in the context of schools in Botswana, many of the social studies teachers appear to lack sound understanding of the values, skills and the global dimensions associated with citizenship competencies. This is consistent with the past study by Kerr (2009) which revealed that social studies teachers are more likely to marginalize certain components if they lack an understanding of the values, skills and global dimensions that underpin citizenship skills. Teachers continue to use the old method of telling their students instead of engaging them to harness information for themselves. This partly stems from the fact that pedagogical approaches suitable to the teaching of citizenship competencies are generally challenging thus teachers are more likely to employ teacher-centered methods. This contrasts markedly with the ideals of the liberal education system that purports to promote values such as tolerance, cooperation, self-respect, honesty, courtesy and integrity.

The above situation is further compounded by the way the curriculum is structured, executed, the general lack of time as well as inadequate curricular materials. For example, the students who are naturally inquisitive are perceived negatively by most social studies teachers. It is not far-fetched to posit that such teachers lack proficiency in critical and reflective thinking because most social studies teachers are not democratic and innovative hence they end up indoctrinating their students rather than promoting problem-solving skills. The purpose of this study is to investigate secondary school teachers' perceptions of the role that social studies plays in 
fostering citizenship competencies and skills. In order to achieve this, the paper poses the following research questions:

1) To what extent does the social studies curriculum promote citizenship competencies and skills?

2) What perceptions do secondary school teachers hold on the role of social studies in fostering citizenship competencies and skills among Batswana students?

3) What are the alternative ways of fostering citizenship competencies and skills in the social studies curriculum?

In order to successfully address the research questions posed above, it is important to provide the context for understanding the nature of the relationship between social studies and citizenship education. We propose that as a starting point, it is critical to locate the emergence of social studies in Botswana within the context of the new global social studies movement and in particular, the African Social Studies Program.

\subsection{The Context of Development of Social Studies in African Education and in Botswana}

The close link between social studies and citizenship education is not unique. Of course the link also exists between citizenship and other subjects in the school curriculum. However, the main focus of this paper is to explore the nature of the relationship between teaching and learning of social studies and the acquisition of citizenship competencies. Howe and Marshall (1999) and Roth and Desautels (2004) for instance, see social studies as playing a vital role in the promotion of citizenship education. White (2000) further observes that it entails lifelong learning and preparation for the world of work. For their part, Roth and Desautels (2004) include the decision-making processes concerning controversial, socio-scientific and socio-technical issues. Put differently, social studies seeks to achieve citizenship education and cultivate democratic-minded citizens. Realizing this goal requires a deeper understanding of the pedagogical practices and the teachers' perceptions and their level of awareness of citizenship education.

According to Ten Dam and Volman (2004), citizenship competencies and critical thinking are not only closely linked but are also complex and contested processes. Notwithstanding, citizenship competencies specifically focus on learning to think critically, the acquisition of skills, dispositions and knowledge to participate in the communities. In fact, Ten Dam and Volman's (2004) further observe that active participation is dependent on the acquisition of critical thinking and competencies which are critical for survival in the modern society. For example, at the classroom and school level, citizenship competencies give the students the opportunity to observe, imitate and practice critical agency and make reflections necessary against the backdrop of the rapid pace of globalization.

The emergence and development of social studies in Botswana needs to be understood in the context of the New Social Studies movement and the African Social Studies Program (ASSP). The New Social Studies movement in the United States, in the view of Howe and Marshall (1999), gained currency in the 1950s and 1960s.In Africa it was launched at the Mombasa Social Studies Conference held in 1968 in Kenya. This was an attempt to improve the quality of education in the African continent. Adeyinka (2000) sees the main aim of the conference as charting the way forward for the widespread adoption of the social studies education programme in Africa. To this end, the Mombasa conference adopted ASSP as a vehicle through which African states hoped to reach out to their citizens in terms of achieving their needs and aspirations. Consistent with the ASSP, each country, according to Salia-Bao (2000), had to design its social studies program bearing in mind its needs, children, culture, environment and aspirations. The adoption of the ASSP and its recommendations paved the way for the inclusion of social studies in the African states' school curriculum. The recommendations came handy to the African countries as they all benchmarked using the ASSP as a template and a road-map for their education systems.

In 1968, that is two years after attaining independence, the Botswana government adopted the principles of the ASSP. According to Boikhutso (1993), there was the general feeling that Botswana's education system was colonially-oriented hence not relevant to the needs of its people. The government acceded to public pressure and instituted a commission of inquiry in 1975 which produced the report entitled Education for Kagisano [loosely translated means education for social harmony] in 1977 (Republic of Botswana, 1977). This report spelt out the ideals of democracy, unity, self-reliance and development which augured well with what social studies stands for. As a result, social studies was introduced into the primary and the junior secondary school curriculum for the first time in 1982 by replacing mainly geography and history. The thinking of the Botswana Government was that social studies would enhance the promotion of unity, self-reliance and values that are key to the successful implementation of citizenship education program. 
The social studies curriculum has been in use since then and the latest revision was in 2008 following the recommendation of the 1994 Revised National Policy on Education [RNPE] (Republic of Botswana, 1994). The revision was mainly meant to address the contemporary issues arising from globalization and the ever changing economic needs of the country. The RNPE also recommended the introduction of social studies at senior secondary school level and this was implemented in 2008 and by then it was only offered as an optional subject. The National Commission on Education of 1993 was further complemented by the drawing of the 2016 national vision in 1997 which had "botho" as its fifth national principle. Botho refers to a "person who has a wellrounded character, who is well mannered, courteous and disciplined, and realizes his or her potential both as an individual and as a part of the community to which he or she belongs" (Republic of Botswana, 1997, p. 2). The principle embraces the value of respect which a well-rounded citizen must exhibit in his or her everyday life and entails earning respect by first giving it to others. The document further spells out that "good" citizenship entails someone who is compassionate, tolerant, democratic, just, and caring (Republic of Botswana, 1997). In schools, it is envisaged that the content and teaching and learning methods should as much as possible be aligned to the national Vision 2016. Furthermore, the values are also commensurate with the aims and content of social studies. Despite the good intentions of the national vision, its realization is more likely to fail as long as social studies is not a core subject in the senior secondary school curriculum.

\subsection{The Philosophical Foundations and Traditions of Social Studies Education}

The conventional understanding of social studies is that it refers to the study of relationships among people and between people and the environment while recognizing the challenges and benefits of living in culturally and ideologically diverse societies. Parker (2001) avers that the rationale behind social studies education is to promote reflection, investigative skills and critical awareness of the human condition and emerging spatial patterns and the processes and events that shape them. In the words of Adeyinka (2000) social studies education not only builds on a common understanding of responsible citizens but also imparts citizenship attitudes, values and critical thinking skills. However, critics of social studies such as Griffith (1995) and Howe and Marshall (1999) claim that the subject has essentially drifted away from its original major concerns, aims and intentions.

Social studies as an interdisciplinary academic field is often viewed as synonymous with citizenship education. However as Kerr (1999) proposes there are variations in terms of the conceptualization of citizenship depending on historical circumstances. According to Barr (1977) the extant literature identifies three social studies traditions. First social studies is mainly taught to transmit citizenship skills, knowledge and values. This also entails negotiation skills, decision making skills and enhancement of values of respect and tolerance. The second tradition looks at social studies within the social sciences framework where the focus is to assist students to think about their social world. Barr (1997), DfES (2004) and Salia-Bao (2000) maintain that the key focus is to have students think deeply, understand the world around them, become better citizens capable of making sound decisions and solving problems. The last tradition views social studies as embracing reflective inquiry and critical thinking and advocates for the need to empower learners to apply information to social problems and use intellectual processes to find solutions to problems. In the opinion of Salia-Bao (2000), within this tradition, students are enabled to investigate, analyze issues and find solutions to societal problems.

\subsection{The Citizenship Education}

Several scholars (Cogan \& Derricott, 2000; Kaltsounis, 1979; Parker \& Jarolimek, 1984) see the concept of citizenship as highly contested and understood differently in the literature. Even the terminology varies from one context to the other. Kerr (2009) asserts that this situation is compounded by the fact that a given country's expression of its values has a marked influence on how it defines and/or approaches citizenship education. In other words, the conceptualization of citizenship education is bound to differ from one country to the other. According to Kerr (1999), "citizenship or civics education is construed broadly to encompass the preparation of young people for their roles and responsibilities as citizens and, in particular, the role of education (through schooling, teaching and learning) in that preparatory process" (p. 34). In the view of Kaltsounis (1979) citizenship education aims at developing the capability of individuals to engage in thoughtful and responsible participation in political, social, economic and cultural life of their community. Kerr (2009) notes that when understood in this way, citizenship involves the promotion of participation in decision making, forging strong community links, sensitivity to values and ethics and engagement in the discussion of critical issues such as voting and political debates. In this paper, we use the term citizenship to refer to the behavior, actions and the involvement of citizens in public life.

Tied to the traditions of social studies highlighted above are the four dimensions of citizenship education. These are personal, social, temporal and spatial attributes and are part of the multidimensional model of citizenship education proposed by Quisumbing (2002). The personal dimension refers to one's capacity and commitment to a 
civic ethic characterized by responsible habits of mind, heart and action. The social dimension means the capacity to live and work together for civic purposes. Quisumbing (2002) further understands the spatial dimension as referring to the capacity to see oneself as a member of several overlapping communities at local, national, regional and international level. Lastly, the temporal dimension refers to the capacity to locate challenges in the past, present and future and to stay in touch with reality. The DfES (2000) report interrogates the four dimensions and points out that more often than not most social studies teachers tend to treat the four dimensions as if they are different entities yet they are interrelated. The end result of these dimensions is the production of citizens who are not all-rounded. For example, some are strong in one or two dimensions while others are not pointing to lack of a coherent and holistic approach to citizenship education. It is not an over statement to suggest that the four citizenship dimensions play a major role in facilitating the teaching for citizenship education. Failing to integrate the four citizenship dimensions partly stems from the inadequate teacher preparation. For example during teacher preparation the 'would-be' social studies teachers are mainly taught pedagogical approaches because of the inadequate time allocated to micro teaching and teaching practice.

Somewhat related to the four dimensions discussed above is the passive and active approaches to citizenship. The passive approach emphasizes socialization and the development of loyalty to the nation state while the active approach places emphasis on the engagement of learners and their active participation in reforming societal institutions locally and globally (Thornton, 2005). Under the passive approach, students are taught to be patriotic and proud members of a nation state. In Botswana this is evidenced by the national Vision 2016 which calls for the development of a citizenry which is patriotic and owes allegiance to the nation state (Republic of Botswana, 1997). In contrast, the active approach calls for the engagement of citizens in public debates tackling issues that affect their communities and participating in projects that are geared towards uplifting the poor. The vision rightly captures the active approach when it says Botswana should aim to create citizens who are compassionate, just and caring (Republic of Botswana, 1997).

\subsection{Who is Responsible for Teaching Citizenship Values - Family or School?}

The role of values in the observation of Quisumbing (2002) is often the most neglected and least understood component of the school curriculum. In this context, values can be viewed as attitudinal dispositions desirable for the promotion of citizenship. Specifically, these are virtues like honesty, patriotism, respect, tolerance of ethnic differences and respect for law and authority. But the question of who is responsible for the teaching of values persists in the literature and public discourse? Kaltsounis (1979) and Kerr (2009) think that this question solicits divergent opinions. For example, some people think that the teaching of values is the sole responsibility of parents. Others disagree and think that the schools should teach the values. This raises another question, which is raised by Kerr (2009), of the balance between the 'public' and 'private' dimension of citizenship. Those who see citizenship as a largely 'private' engagement see a much more limited, or 'thin', role for education where it is promoted through the hidden curriculum. Here, there is advocacy for a much stronger role of the family and community organizations than for teachers since parents spend most of the time with their children and would know of the societal values which they may easily transfer to them.

According to Kerr (2009), those who say teachers teach values claim that they (teachers) are better placed as they are the 'creators of knowledge'. In other words, as loco-parentis, teachers have the duty and responsibility to turn children into 'good' citizens. However, as Kerr (2009) rightly observes, both approaches to the teaching of citizenship values have been criticized. For example, the 'values-explicit' approaches based on the family have been accused of indoctrinating students, while 'values-neutral' proponents have been found to fail to help students to deal adequately and appropriately with the real-life situations and controversial issues. Furthermore, citizenship education has been found not to be value-free and neutral.

\section{Method}

\subsection{Research Design}

This study focused on the perceptions of the secondary school teachers on the role that social studies plays in fostering citizenship education. The investigators applied quantitative research techniques to obtain the required data. Participants were given questionnaires to fill during their spare time so that they could provide well thought responses. However, a short meeting was arranged with each of the participants prior to the completion of the questionnaires during which the purpose of the study was explained. The use of survey questionnaires allowed the investigators the opportunity to gather more information in a flexible manner. As Creswell and Miller (2000) rightly observe, perceptions are internal processes that are not explicitly observable. Hence, the use of questionnaires provides an alternative, quicker and easier means of capturing perceptions. 


\subsection{Participants and Sampling Procedures}

The population of the study consisted of a total of forty-one respondents picked from nine secondary schools. Out of the five junior secondary schools, two were located in urban and three in rural areas. Two of the senior secondary schools were located in urban and another two in rural areas. Thirty-four of these were social studies teachers while seven were head of departments. The forty-one participants were purposively sampled from the southern and south-central inspectorate regions of Botswana. According to Hatch (2002), purposive technique is a form of non-probability sampling where the selection of participants depends on the investigators' judgments and the need to obtain rich data.

\subsection{Description of Survey}

The questionnaires used to collect data comprised open-ended and close-ended items. These covered an array of issues including but not limited to: teaching experience; educational qualifications; area of specialization; reflections on the school learning environment; motivation; democratic governance; participation in decision-making and action oriented activities; quality of lesson preparation and planning; classroom assessment and reflection; instruction and student engagement; quality of teacher preparation program and the extent to which social studies promotes the acquisition of citizenship competencies and skills. The research instruments were piloted in two phases. The initial piloting was done in May 2010 targeting six in-service social studies teachers enrolled in a Master of Education program at the University of Botswana. The second phase of piloting was extended to one senior secondary school in an urban location and a junior secondary school in a rural location. The feedback from piloting enabled the investigators to make minor revisions to the research instruments before the commencement of data collection in the last two weeks of June in 2010.

\subsection{Issues of Validity and Reliability}

Given that this study is mainly descriptive applying non-probability sampling techniques, the investigators applied triangulation as a means of minimizing bias. In order to achieve this, validity and reliability were used as safeguard mechanism for ensuring the accuracy of the data collected. Validity ensured the relevance and appropriateness of information to the problem under investigation. Reliability ensured the consistency, dependability and trustworthiness of the data. According to Pierce (2008), triangulation is the means adopted by researchers to secure effective collaboration of data. As part of the data collection process, the investigators made a deliberate attempt to ask similar questions to the different actors (i.e. teachers and head of departments, in different locations (i.e. rural and urban) and levels of schooling (i.e. junior and secondary). This approach allowed the investigators the opportunity to determine similarity and differences in the responses generated from the participants.

\subsection{Data Analysis}

The information collected from closed-ended items was analyzed using descriptive statistics such as tables, frequency counts and percentages. According to Gay and Airason (1992), data analyzed numerically is easy to understand and also provides clear patterns to enable quick interpretation of the data. In contrast, information obtained from open-ended items was coded into separate categories and themes. In the view of Mertens (1998), coding is an interpretive technique that allows one to organize data into meaningful categories. The responses of the head of departments were captured and analyzed separately. This was occasioned by virtue of their privileged positions within the school management teams.

\subsection{Ethical Consideration}

Permission to undertake research was sought from all the relevant officials such as the University of Botswana, Ministry of Education and Skills Development, schools and the participating teachers and head of departments. The principle of informed consent was taken into account by assuring the respondents that all the information provided was to be treated with confidentiality. Respondents were also informed that they had the right to withdraw from participating in the study anytime they wished.

\section{Results}

\subsection{Social Studies and Citizenship Competencies}

Forty (98\%) of the sampled respondents indicated that social studies provides students with the necessary skills, knowledge, values and attitudes relevant for effective participation in community activities. Only one (2\%) respondent felt that social studies curriculum does not facilitate citizenship skills as it purports to do. Interestingly, all the sampled head of departments strongly felt that social studies equips learners with citizenship skills and competencies. Overall, these results do not demonstrate important differences in the perceptions held by the teachers in junior and senior secondary schools. Similarly, there are no observable differences in the perceptions of 
the teachers in urban and rural schools. However, important differences seem to crop-up between teachers in junior secondary schools, their senior secondary counter parts and the head of departments. Junior secondary teachers appear to have the propensity to critique the role that social studies plays in the promotion of citizenship competencies. This is partly explained by the fact that during their college training, they are largely exposed the different components of social studies education. In contrast, teachers in senior secondary schools and head of departments across the schools are more likely to hold a divergent view. The majority of teachers in the senior secondary schools and head of departments are not necessarily social studies specialists. Many of them have been trained in history, geography, sociology and other related fields.

Table 1. Social Studies and Acquisition of Citizenship Skills

\begin{tabular}{lcccc}
\hline & $\begin{array}{c}\text { Social Studies Equips } \\
\text { Learners with } \\
\text { Citizenship Skills (n) }\end{array}$ & Not Sure (n) & $\begin{array}{c}\text { Social Studies Does Not } \\
\text { Equip Learners with } \\
\text { Citizenship Skills (n) }\end{array}$ & Total of Participants \\
\hline $\begin{array}{l}\text { Junior Secondary } \\
\text { Teachers }\end{array}$ & 5 & - & - & 5 \\
Urban Rural & 14 & - & 1 & 15 \\
Senior Secondary & 7 & - & - & 7 \\
Teachers & 7 & - & - & 7 \\
Urban Rural & 3 & - & - & 3 \\
Head of & 4 & - & - & 4 \\
Department & $40(98 \%)$ & - & $1(2 \%)$ & $41(100 \%)$ \\
Urban Rural & & & & \\
Total $(\%)$ & &
\end{tabular}

\subsection{Social Studies and Civic Competencies}

Twenty-two (65\%) of the respondents said that social studies is a platform through which civic competencies are relayed and two $(6 \%)$ of the respondents were not sure while ten $(29 \%)$ disagreed. All the sampled head of departments had strong views about the close relationship between social studies and citizenship competencies. Although most of the respondents were of the view that civic competencies can be acquired through the teaching of citizenship education, the number of those who were not sure and those who disagreed is startling. It appears that the nature of the linkages between social studies and civic competencies is not very clear to the respondents. That there was, a substantial number of the combined respondents who were not sure and also disagreed, points to the general failure of teachers to appreciate civic competencies as an integral part of social studies. This is a reflection of a number of factors such as inadequate teacher preparation, curricular materials and lack of proficiency in critical reflective thinking and problem solving skills.

Table 2. Social Studies as a Platform for Relaying Civic Competencies

\begin{tabular}{lllll}
\hline & $\begin{array}{c}\text { Social Studies is a Platform for } \\
\text { Relaying Civic } \\
\text { Competencies (n) }\end{array}$ & $\begin{array}{c}\text { Not } \\
\text { Sure } \\
\text { (n) }\end{array}$ & $\begin{array}{c}\text { Social Studies is Not a Platform } \\
\text { for Relaying Civic } \\
\text { Competencies (n) }\end{array}$ & $\begin{array}{c}\text { Total of } \\
\text { Participants }\end{array}$ \\
\hline $\begin{array}{l}\text { Junior Secondary } \\
\text { Teachers }\end{array}$ & 1 & 1 & 3 & \\
Urban Rural & 7 & 1 & 7 & 5 \\
Senior Secondary & & - & - & 7 \\
Teachers & 7 & - & - & 7 \\
Urban Rural & 7 & $2(6 \%)$ & $10(29 \%)$ & $34(100 \%)$ \\
Total (\%) & $22(65 \%)$ & & & \\
\hline
\end{tabular}

\subsection{Social Studies and Decision Making Processes}

Twenty-four (71\%) of the respondents sampled indicated that their students acquired critical skills which enabled the latter to make informed decisions and thus become knowledgeable citizens. Only one (3\%) was not sure while nine $(26 \%)$ of the respondents disagreed. These results too do not reveal important differences in the responses according to teachers in the junior and senior secondary schools and according to rural-urban location. The only important observation is that all the sampled head of departments noted the interrelationship between 
the acquisition of critical skills and decision making processes. This is not surprising given their propensity to protect the status quo as members of the senior management team. Besides, social studies teachers continue to use teacher-centered pedagogies rather than learner-centered approaches which are consistent with the underlying principles of citizenship education.

Table 3. Acquisition of Critical Skills

\begin{tabular}{lllll}
\hline & $\begin{array}{c}\text { Social Studies Students are } \\
\text { Able to Make Informed } \\
\text { Decisions (n) }\end{array}$ & $\begin{array}{c}\text { Not } \\
\text { Sure } \\
\text { (n) }\end{array}$ & $\begin{array}{c}\text { Social Studies Students are Not } \\
\text { Able to Make Informed } \\
\text { Decisions (n) }\end{array}$ & $\begin{array}{c}\text { Total of } \\
\text { Participants }\end{array}$ \\
\hline $\begin{array}{l}\text { Junior Secondary } \\
\text { Teachers }\end{array}$ & 2 & 1 & 3 & 5 \\
Urban Rural & 8 & & 2 & 15 \\
Senior Secondary & & - & 2 & 7 \\
Teachers & 7 & - & 2 & 7 \\
Urban Rural & 7 & $1(3 \%)$ & $9(26 \%)$ & $34(100 \%)$ \\
Total (\%) & $24(71 \%)$ & & & \\
\hline
\end{tabular}

\subsection{Social Studies and Problem-Solving Skills}

Twenty-one (62\%) of the sampled respondents said that the social studies curriculum helps to develop students who are effective problem solvers and decision makers. Ten (29\%) disagreed and $3(9 \%)$ were not sure. As expected, all the sampled head of departments claimed that the social studies curriculum helps students to become effective problem solvers. Practically speaking, this is one instance of the mismatch between theory and practice or a typical example where words and deeds are dialectically opposed. From the responses generated from the participants, there is no indication that the learners do acquire decision-making and problem-solving skills in the process of learning social studies.

Table 4. Acquisition of Problem Solving Skills

\begin{tabular}{lllll}
\hline & $\begin{array}{c}\text { Social Studies Equips } \\
\text { Learners with Problem } \\
\text { Solving Skills (n) }\end{array}$ & $\begin{array}{c}\text { Not } \\
\text { Sure } \\
(\mathrm{n})\end{array}$ & $\begin{array}{c}\text { Social Studies Does Not Equip } \\
\text { Learners with Problem Solving } \\
\text { Skills (n) }\end{array}$ & $\begin{array}{c}\text { Total of } \\
\text { Participants }\end{array}$ \\
\hline $\begin{array}{l}\text { Junior Secondary } \\
\text { Teachers }\end{array}$ & 2 & 1 & 2 & 5 \\
Urban Rural & 11 & 2 & 2 & 15 \\
Senior Secondary & & - & 4 & 7 \\
Teachers & 3 & - & 2 & 7 \\
Urban Rural & 5 & $3(9 \%)$ & $10(29 \%)$ & $34(100 \%)$ \\
Total (\%) & $21(62 \%)$ & & & \\
\hline
\end{tabular}

\subsection{Social Studies, Teaching Methods and Citizenship Education}

Nineteen (59\%) respondents felt that the teaching and learning of social studies fosters the acquisition of citizenship skills. Twelve (35\%) felt it is primarily concerned with skills development, eleven $(32 \%)$ felt it promotes critical thinking while $8(24 \%)$ felt social studies was largely concerned with the transmission of values. It is one thing to claim that social studies fosters the varied skills and competencies related to citizenship education and it is yet another story to prove if indeed what is being said is actually put into practice. What we do know though is that the implementation of citizenship education is not only problematic but it is also a contested terrain. 


\section{Discussion}

The findings of this study are intriguing in several respects. First, they suggest that generally social studies equips students with citizenship skills. This line of thinking is confirmed by Preece and Mosweunyane (2003) who suggest that one of the main goals of social studies is to stimulate high aspiration, confidence, improved skills and attitudes. Howe and Marshall (1999) and Miller (1993) also demonstrate that the other core principle underpinning citizenship education is active and meaningful social participation. This also entails the promotion of civic responsibility, intellectual skills, participatory skills, research and persuasion as key to citizenship education (Howe \& Marshall, 1999; Torney-Purta \& Vermeer, 2004). However, it is debatable whether or not in the context of Botswana's social studies curriculum this is being achieved on the ground. The situation on the ground tells a different story. For example, an overwhelming majority (98\%) of the respondents claim that social studies promotes citizenship skills yet it is doubtful that the mere teaching of citizenship skills automatically translates into equipping learners with the relevant and appropriate skills to actively participate in community activities. It can be argued that contrary to expectations, the introduction of social studies in Botswana school curriculum in the early 1980's has not led to the improved quality education in general and the promotion of citizenship skills and competencies in particular. As Adeyinka (2000) rightly observed, the rationale behind the African Social Studies Program was the need to provide relevant education to the learners needed for survival in the global economy.

Second, the findings underline the relationship between citizenship education and sound decision making. This is consistent with past studies (Howe \& Marshall, 1999; Schug \& Beery, 1987) which suggested that citizenship knowledge and attitudes can help citizens make sound decisions. In contrast, people who are not well informed are likely to depend heavily on the opinions of others. That a substantial number (26\%) of the respondents disagreed requires further interrogation. In fact, this is a clear indication of the failure of the Botswana's social studies curriculum to inculcate appropriate and relevant citizenship skills. Ten Dam and Volman (2004), for example, remind us of the importance of critical thinking and the acquisition of civic skills in the rapidly developing global economy. In fact, it is one thing for students to learn critical thinking and another to use them. Past studies like that of Halpern (1998) revealed that the acquisition of critical skills involves knowing when to use and the willingness to apply the skills. Hence there is no point in teaching students the skills in critical thinking if they will not use them. Howe and Marshall (1999) remind us that one of the main ways through which social studies can achieve the goal of citizenship education is through the creation of well informed and knowledgeable citizens

Third, the findings of this study from a theoretical perspective demonstrate the link between citizenship education, problem solving and critical thinking. And as Howe and Marshall (1999) and Engle and Ochoa (1988) rightly observe the acquisition of problem-solving skills and competencies such as critical thinking, cognitive, academic, social and interpersonal skills are necessary for functioning in today's increasingly complex and global environment. In order for social studies to facilitate the development of these skills, it is important that the learning and teaching processes go beyond textbook use and classroom interaction. Howe and Marshall (1999) further note that it is necessary to involve and engage students in real life learning experiences, meaningful and actively in addressing community issues. What is intriguing is the positive perceptions held by both junior and secondary teachers (irrespective of the urban-rural divide) that social studies fosters citizenship competencies among Botswana learners. However, there is no evidence to demonstrate that the philosophical foundations underpinning the teaching and learning of social studies are translated into practice in the Botswana schools. It is important for the change agents to be mindful of what Salia-Bao (2000) terms the key focus of social studies education - the preparation of better citizens capable of making sound decisions and engaging in problem solving activities.

Lastly the findings of this study demonstrate that very few (24\%) of the sampled respondents seemed to appreciate the role of social studies in facilitating the development of appropriate values. That is, Botswana's social studies curriculum is failing to facilitate the core values of citizenship education. In fact, Kerr (2009) is spot on in suggesting that teachers as 'creators of knowledge' (though this is a contested claim) are better placed to teach citizenship values. Contrary to what past studies (e.g. Howe and Marshall 1999) have shown Botswana's social studies curriculum is failing to achieve the goal of citizenship education --helping learners to acquire values that are consistent and supportive of democracy. These values include tolerance, participation in decision making and equality of opportunity which largely reflect wider liberal values. Engle and Ochoa (1988), however, observe that the values are not a 'given' as they tend to be inherently political, controversial and not fixed. Hence their application is context specific and each generation will necessarily reinterpret them. In other words, social studies teaching and learning processes in the Botswana context need to take into account the role of values in fostering understanding and resolving social issues. 


\section{Conclusion}

\subsection{Social Studies and Acquisition of Citizenship Skills}

The findings of the study point to the fact that the Botswana's social studies curriculum is failing to promote the acquisition of citizenship skills. Social studies teachers generally perceive their subject as critical in helping learners become responsible, well informed and self-reliant citizens who can function independently. However, there appears to be a disconnection between what social studies teachers think and do on the one hand and what actually happens on the ground on the other hand. The respondents talked about the theoretical goals of social studies and citizenship education and did not necessarily say they themselves were imparting such skills. What this supposedly means is that the realization of social studies goals requires the combination of teachers' and political commitment if the education system is to be transformed. Thus citizenship competencies and skills need to be politically driven by social studies teachers who are well trained and competent to handle educational reforms.

\subsection{Limitations}

There is need for caution in interpreting the results of this study. This stems from the use of purposive sampling a non-probability sampling technique which in the view of Pierce (2008) does not generate generalizable data. The results of this study are therefore applicable in so far as the research sites used are concerned.

\subsection{Future Research}

The close relationship between social studies teaching-learning and the acquisition of citizenship skills and competencies is not only valid but also genuine. However, the results of this study do not provide a sufficient ground to suggest more sustainable alternative ways of fostering citizenship competencies and skills in the Botswana's social studies curriculum. Further research should as a matter of fact attempt to replicate this study in an in-depth manner by adopting more robust and statistically reliable probability sampling procedures. Such an approach will yield a larger sample size thus allow for the generalization of data.

\section{References}

Adeyinka, A. A. (2000). Philosophical foundations of socials studies education in Africa. In M. B. Adeyemi (Ed.), Social Studies in African Education (pp. 13-24). Gaborone: Pyramid Publishers.

Barr, R. D. (1977). Defining social studies. Defining the Social Studies. Bulletin 51. Washington, DC: National Council for the Social Studies.

Boikhutso, K. (1993). Vocationalization of the school curriculum in Botswana,(Masters Dissertation), University of Bristol, United Kingdom.

Cogan, J. J., \& Derricott, R. (2000). Citizenship for the $21^{\text {st }}$ century:-An internal perspective on education. London: Allyn and Bacon.

Creswell, J. W., \& Miller, D. L. (2000). Determining validity in qualitative inquiry. Theory into Practice, 39(3), 124-131. http://dx.doi.org/10.1207/s15430421tip3903 2

DfES. (2004). Developing a global dimension in the school curriculum. London: DfES.

Engle, S. H., \& Ochoa, A. S. (1998). Education for democratic citizenship: Decision making in the social studies. New York: Teacher's College Press.

Gay, L. R., \& Airason, J. (1992). Educational research competencies for analysis and application. Ohio: Prentice Hall. Griffith, A. D. (1995). Social participation as a major goal in social studies: towards authentic instruction and learning in Caribbean schools. Caribbean Curriculum, 5(2), 47-66.

Halpern, D. F. (1998). Teaching critical thinking for transfer across domains. Dispositions, skills, structure training and metacognitive monitoring. American Psychologist, 53(4), 449-455. http://psycnet.apa.org/journals/amp/53/4/449.pdf

Hatch, A. (2002). Doing qualitative research in education settings. Albany: Albany State of New York Press.

Howe, G. D., \& Marshall, D. D. (1999). Citizenship education, democracy and global shifts: Re-thinking Carribean social studies. Kingston: UNESCO, Retrieved from http://unesdoc.unuseco.org

Kaltsounis, T. (1979). Teaching Social Studies in the elementary school: The basic for citizenship. New Jersey: Prentice Hall.

Kerr, D. (1999). Citizenship Education: An international comparison, International Review of Curriculum and Assessment Frameworks Archive, Retrieved from www.inca.org.uk/thematic.asp. 
Kerr, D. (2009). Citizenship and values education to the rescue! Making the case for call to action. Executive summary of the ninth conference. London: Institute for Global Ethics/Gordon Foundation.

Mertens, D. M. (1998). Research methods in education: Integrating diversity with quantitative and qualitative approaches. London: Sage Publications.

Miller, R. (Ed.). (1993). Orientation to Social Studies education. New York: Macmillan Publishing Company.

Parker, W., \& Jarolimek, J. (1984). Citizenship and the critical role of the social studies. Washington: National Council for Social Studies.

Parker, W. C. (2001). Social studies in elementary education (1 $11^{\text {th }}$ ed.). Ohio: Merrill Prentice Hall.

Pierce, R. (2008). Research methods in politics. A practical guide. London: Sage Publications Ltd.

Preece, J., \& Mosweunyane, D. (2003). Perceptions of citizenship responsibility amongst Botswana youth. Gaborone: Lightbooks.

Quisumbing, L. R. (2002). Citizenship education for better world societies: A holistic approach. Paper read at the $8^{\text {th }}$ UNESCO APEID International Conference on Education, 29 November 2002, Bangkok.

Republic of Botswana. (1994). Revised national policy on education, Gaborone: Government Printers.

Republic of Botswana. (1997).The presidential taskforce: Vision 2016 - Towards prosperity for all. Gaborone: Government Printers.

Republic of Botswana. (1977). Education for kagisano. Gaborone: Government Printers.

Roth, W. M., \& Desautels, J. (2004). Educating for citizenship: reappraising the role of science education. Canadian Journal of Science, Mathematics and Technology, 4(2), 149-168. http://dx.doi.org/10.1080/14926150409556603

Salia-Bao, K. (2000). African Social Studies programme: A handbook for teachers. Ibadan: Evans Brothers Limited.

Schug, M. C., \& Beery, R. (1987). Teaching social studies in the elementary school:- Issues and practices. London: Scott, Foresman and Company.

Seefeldt, C. (1984). Social studies for the pre-primary child ( $2^{\text {nd }}$ ed.). Columbus: Bell and Howell Company.

Ten Dam, G., \& Volman, M. (2004). Critical thinking as a citizenship competence: teaching strategies. Learning and Instruction, 14(4), 359-379. http://dx.doi.org/10.1016/j.learninstruc.2004.01.005

Thornton, S. J. (2005). Teaching social studies that matters: Curriculum for active learning, New York: Teachers College Press.

Torney-Purta, J., \& Vermeer, S. (2004). Developing citizenship competencies from kindergarten through grade 12: A background paper for policymakers and educators. Denver, CO.

White, C. (2000). Issues in Social studies:-Voices from the classroom. Springfield: Charles C. Thomas.

\section{(c) $\mathbf{E Y}$}

This work is licensed under a Creative Commons Attribution 3.0 License. 